\title{
PENGARUH THERAPI PSIKOEDUKASI KELUARGA TERHADAP KEMAMPUAN KELUARGA DALAM MERAWAT LANSIA DIABETES MELLITUS TIPE 2 DI KOTA TASIKMALAYA
}

\author{
Ridwan Kustiawan ${ }^{1}$, Hj. Peni Cahyati' ${ }^{2}$ Siti Badriah ${ }^{3}$ \\ ${ }^{1,2,3}$ Dosen Jurusan Keperawatan Poltekkes Kemenkes Tasikmalaya
}

\begin{abstract}
ABSTRAK
Hasil Riset Kesehatan Dasar (RISKESDAS, 2007) menunjukkan penderita Diabetes Militus di Indonesia usia 65 sampai usia 74 tahun berjumlah 2,4\% dan usia 75 tahun keatas berjumlah $2,2 \%$. Sementara itu di Kota Tasikmalaya dalam satu tahun terakhir ini terdapat 547 orang lansia usia 60 tahun keatas yang teridentifikasi mempunyai penyakit DM atau sekitar $0,7 \%$. Tujuan penelitin ini untuk membuat penilaian terhadap gambaran kemampuan keluarga dalam merawat lansia diabetes mellitus tipe 2 sebelum dan sesudah therapi psikoedukasi keluargaJenis penelitian yang dilakukan adalah penelitian analitik dengan pendekatan quasi eksperiman,. Teknik Sampling yang digunakan adalah konsekutif sampling, yang terdiri dari 20 kelompok intervensi dan 20 kelompok kontrol. Hasil penelitian menunjukkan ada peningkatan kemampuan kognitif dan psikomotor pada kelompok intervensi yang mendapatkan terapi Psikoedukasi keluargayaitu kemampuan kognitif sebelum perlakukan 7,90 setelah perlakukan menjadi 10,70 sedangkan kemampuan psikomotor sebelum perlakuan 11,20 menjadi 15,75 . Sementara kelompok yang tidak dilakukan terapi psikoedukasi keluarga tidak terdapat peningkatan kemampuan dalam merawat lansia dengan DM tipe 2. Berdasarkan hasil tersebutmaka terapi psikoedukasi keluarga dapat meningkatkan kemampuan keluarga dalam merawat klien lansia dengan Diabetes militus tipe 2.
\end{abstract}

Kata Kunci : Terapi Psikoedukasi, DM Tipe 2

\begin{abstract}
Basic Healthresult (RISKESDAS, 2007) Showed Diabetes Militus patients in Indonesia age 65 to age 74 years amounted to $2.4 \%$ and age 75 years and older amounted to $2.2 \%$. Meanwhile in Tasikmalaya the past year, there were 547 elderly people aged 60 years and older identified as having DM, or about $0.7 \%$. This was analytical research with quasi experimental approach. This research aimed to make an assessment of family ability caring eldery people with type 2 Diabetic before and after family psychoeducation theraphy. Sampling technique used was a consecutive sampling, Which comprised of 20 intervention in people and 20 contro inpeople group. The results showed an increase in cognitive and psychomotor abilities in the intervention group with cognitive ability before treatment 7.90 , and after treatment became 10.70. whereaspsychomotor ability before treatment 11.20 and after treatment becomes 15.75. Control group that did not do family psychoeducation showed therapyno increased ability to care for elderly people with type 2 diabetes mellitus. Conclusion family psychoeducation therapy can enhance the ability of families in caring for elderly clients with type 2 diabetes.
\end{abstract}

Keyword : Psychoeducation therapy, Type 2 Diabetic 


\section{Pendahuluan}

Salah satu indikator keberhasilan pembangunan adalah semakin tingginya usia harapan hidup (UHH) penduduk. Kementrian Koordinator Bidang Kesra (2012) melaporkan bahwa, pada tahun 2012 UHH di Indonesia mencapai 67,4 tahun, hal ini menyebabkan jumlah penduduk lanjut usia (lansia) terus meningkat dari tahun ke tahun. Depkominfo (2009) melaporkan bahwa tahun 2010 penduduk lansia mencapai 23 juta jiwa, dan tahun 2020 diprediksi akan menjadi 28 juta orang. Data dari Sistem Pencatatan dan Pelaporan Puskesmas Dinas Kota Tasikmalaya (2012) menunjukkan bahwa jumlah lansia di kota Tasikmalaya pada tahun 2012 sebanyak 48.078 orang.

Laporan Badan Penelitian dan pengembangan Kesehatan (2008) bahwa hasil Riset Kesehatan Dasar (RISKESDAS) tahun 2007 menunjukkan penderita DM usia 65 sampai usia 74 tahun berjumlah $2.4 \%$ dan usia 75 tahun keatas berjumlah 2.2\%. Sementara itu di Kota Tasikmalaya terdapat $547(0,7 \%)$ lansia usia 60 tahun keatas yang teridentifikasi menderita penyakit Diabetes Militus(SP3 Dinas Kota Tasikmalaya, 2012). Berdasarkan hal tersebut lansia merupakan populasi yang perlu mendapat perhatian dari pemberi pelayanan kesehatan karena dampak dari DM dapat menimbulkan permasalahan bagi lansia itu sendiri dan berpotensi menimbulkan beban bagi keluarga yang merawatnya

Beandlands et.al (2005) melaporkan pengalaman keluarga dalam merawat anggota keluarga penyakit DM menimbulkan

\section{METODOLOGI PENELITIAN}

Jenis penelitian ini yaitu penelitian analitik dengan pendekatan Quasi experimental pre-post test with control group" dengan intervensi terapi psikoedukasi keluarga, yang bertujuan untuk membuat penilaian terhadap gambaran kemampuan keluarga dalam merawat lansia diabetes melitus tipe 2 sebelum dan sesudah therapi psikoedukasi. Populasi dalam penelitian ini dampak terhadap fisik, emosi, sosial dan ekonomi. Hasil studi pendahuluan terhadap delapan keluarga yang merawat lansia DM di kota Tasikmalaya, lima diantaranya mengatakan bahwa sulit sekali memberitahu lansia untuk berpantang terhadap makanan yang manis-manis, lansia seringkali marahmarah jika diingatkan untuk berpantang. Tiga keluarga mengatakan kadang-kadang merasa kelelahan dan frustasi merawat lansia DM yang susah diatur. Keluarga yang merawat anggota keluarga dengan DM memerlukan waktu yang cukup lama, disamping keluarga membutuhkan cara merawat penyakit secara fisik keluarga juga memerlukan dukungan psikologis dalam menghadapi anggota keluarga dengan penyakit DM. Kondisi ini mengisyaratkan bahwa dibutuhkan adanya pelayananyang berkualitas dari perawat untuk mendukung keluarga dalam memberikan perawatan pada lansia dengan penyakit DM di rumah.

Terapi psikoedukasi keluarga dirancang untuk meningkatkan pengetahuan keluarga tentang penyakit DM dan perawatannya, peningkatan dukungan bagi keluarga, serta menurunkan intensitas emosi dalam keluarga sampai pada tingkatan yang rendah dengan mengajarkan teknik-teknik manajemen stress dan membicarakan bersama beban yang dirasakan keluarga serta adanya bantuan dari komunitas terhadap keluarga yang mempunyai anggota keluarga dengan DM. Hal ini diharapkan hal akan berdampak pada peningkatan kemampuan keluarga dalam merawat lansia DM di rumah.

adalah semua lansia yang mengalami diabetes tipe 2 di wilayah Kota Tasikmalaya sebanyak 547 orang. Sedangkan sampel dalam penelitian ini 18 orang dengan menggunakan teknik sampling konsekutif sampling, kemudian ditambah 10\% untuk menghindari drop out, sehingga sampelnya menjadi 20 orang. Analisis bivariat menggunakan uji independent sample t-tes. 


\section{HASIL PENELITIAN}

1. Uji kesetaraan pada kelompok kontrol dan kelompok intervensi dengan uji chi square

Tabel 1. Uji kesetaraan kemampuan keluarga merawat klien lansia DM tipe 2 antara kelompok kontrol dengan kelompok intervensi sebelum psikoedukasi keluarga

\begin{tabular}{lccc}
\hline \multicolumn{1}{c}{ Variabel } & Kelompok & Mean & P value \\
\hline Kemampuan keluarga & Intervensi & 7,90 & 0,155 \\
Kognitif & & 11,20 & \\
Psikomotor & Kontrol & 6,20 & 0,336 \\
\hline Kognitif & 9,45 & \\
Psikomotor & & & \\
\hline
\end{tabular}

Tabel 1 diketahui mean antara kelompok intervensi dengan kelompok kontrol tidak jauh berbeda. Nilai $p$ value kemampuan keluarga lebih dari 0,05 artinya bahwa tidak ada perbedaan antara kemampuan keluarga baik kognitif maupun psikomotor pada kelompok intervensi dan kelompok kontrol sebelum pemberian terapi psikoedukasi keluarga.

2. Gambaran kemampuan keluarga dalam merawat lansia DM tipe 2 di wilayah kerja Puskesmas Kahuripan Kota Tasikmalaya

Tabel 2. Analisis perbedaan kemampuan kognitif dan psikomotor keluarga kelompok intervensi sebelum dan sesudah psikoedukasi keluarga

\begin{tabular}{lcccc}
\hline \multicolumn{1}{c}{ Variabel } & Mean & SD & Min-maks & P value \\
\hline Kemampuan Kognitif : & 7,90 & 3,64 & $1-12$ & 0.001 \\
Sebelum & 10,70 & 3,73 & $9-12$ & \\
Sesudah & 2,80 & & & \\
Selisih & & & & \\
Kemampuan psikomotor: & 11,20 & 6,31 & 0.001 \\
Sebelum & 15,75 & 15,75 & $10-20$ & \\
Sesudah & 4,55 & & & \\
Selisih &
\end{tabular}

Tabel 2 diketahui pada kelompok intervensi kemampuan keluarga aspek kognitif dan psikomotor dengan $p$ value 0,001 artinya ada perbedaan yang bermakna kemampuan kognitif dan psikomotor pada kelompok intervensi sebelum dan sesudah dilakukan psikoedukasi keluarga.

Tabel 3. Analisis perbedaan kemampuan kognitif dan psikomotor keluarga pada kelompok kontrol sebelum dan sesudah psikoedukasi keluarga

\begin{tabular}{lcccc}
\hline \multicolumn{1}{c}{ Variabel } & Mean & SD & Min-maks & $P$ value \\
\hline Kemampuan Kognitif : & & & & \\
Sebelum & 6,20 & 3,76 & $0-12$ & 1,0 \\
Sesudah & 6,30 & 3,76 & $1-12$ & \\
Kemampuan psikomotor: & & & & \\
Sebelum & 9,45 & 4,91 & $3-19$ & 1,0 \\
Sesudah & 9,55 & 4,91 & $3-19$ & \\
\hline
\end{tabular}

Tabel 3. diketahui nilai $p$ value lebih dari 0,05 , sehingga dapat disimpulkan bahwa tidak ada perbedaan antara sebelum intervensi dan setelah intervensi pada kelompok kontrol. 


\section{Perbedaan kemampuan keluarga merawat lansia DM tipe 2 antara kelompok intervensi dan kelompok kontrol}

Tabel 4. Analisis perbedaan kemampuan kognitif dan psikomotor keluarga pada kelompok kontrol dan kelompok intervensi sesudah psikoedukasi keluarga

\begin{tabular}{lcccc}
\hline \multicolumn{1}{c}{ Variabel } & Mean & SD & Min-maks & P value \\
\hline Kemampuan Kognitif : & 7,90 & 0,73 & $9-12$ & 0,001 \\
Kelompok intervensi & 6,20 & 3,76 & $1-12$ & \\
Kelompok kontrol & 1,70 & & & \\
Selisih & & & & \\
Kemampuan psikomotor: & 15,75 & 2,92 & $10-20$ & 0,001 \\
Kelompok intervensi & 9,55 & 4,99 & $3-19$ & \\
Kelompok kontrol & 24,08 & & & \\
Selisih & & & \\
\hline
\end{tabular}

Tabel 4. diketahui nilai $p$ valuenya 0,001 artinya ada perbedaan yang bermakna pada kemampuan keluarga antara kelompok

\section{PEMBAHASAN}

Hasil analisis menunjukkan skor kemampuan kognitif keluarga sebelum pemberian psikoedukasi pada kelompok intervensi adalah 7,90 dan setelah mendapatkan terapi psikoedukasi keluarga menjadi 10,70 dengan $p$ value 0,001 . Artinya terdapat perbedaan yag bermakna pada kelompok intervensi antara sebelum dilakukan terapi psikoedukasi dengan setelah dilakukan terapi psikoedukasi keluarga. Kemampuan kognitif akan membentuk cara berfikir seseorang untuk memahami faktor yang berkaitan dengan kondisinya dan berhubungan dengan perubahan perilaku (Notoatmodjo, 2003).

Hal ini sependapat dengan Notoatmojo (2003), menyatakan pengetahuan dapat menimbulkan kesadaran sehingga pada akhirnya dapat menyebabkan orang berperilaku sesuai dengan pengetahuan yang dimiliki. Hasil atau perubahan perilaku dengan cara ini memakan waktu lama tetapi perubahan yang dicapai akan bersifat langgeng karena berdasarkan kesadaran mereka sendiri. Biasanya perilaku yang didasari dengan pengetahuan akan sulit untuk dirubah oleh orang lain karena hal tersebut timbul dari keyakinannya.Menurut Weine et all (2005) dalam penelitiannya pada 30 keluarga dengan penyakit mental pasca kontrol dengan kelompok intervensi setelah dilakukan psikoedukasi keluarga.

perang Kosovo dengan membandingkan tahun sebelum dilakukan psikoedukasi keluarga terjadi peningkatan pengetahuan tentang penyakit mental, pentingnya obat dan pelayanan kesehatan.

Terapi psikoedukasi keluarga dapat meningkatkan kemampuan keluarga karena dalam terapi mengandung unsur meningkatkan pengetahuan keluarga tentang penyakit, mengajarkan teknik yang dapat membantu keluarga untuk mengetahui gejalagejala penyimpangan perilaku serta peningkatan dukungan bagi anggota keluarga itu sendiri. Tujuan program pendidikan ini, meningkatkan pencapaian pengetahuan keluarga tentang penyakit, mengajarkan keluarga bagaimana teknik pengajaran untuk keluarga dalam upaya membantu mereka melindungi keluarganya dengan mengetahui gejala-gejala perilaku dan mendukung kekuatan keluarga (Stuart \& Laraia, 2005).

Analisa peneliti terkait dengan peningkatan kemampuan kognitif keluarga dalam merawat klien dengan lansa DM tipe 2 yaitu keluarga yang merawat jarang mendapatkan pengetahuan tentang masalah DM, mereka selama ini hanya mendapatkan obat saja yang diberikan dari puskesmas tanpa diberitahu cara perawatan di rumah. Sebagian besar keluarga merasa 
membutuhkan tentang materi DM sehingga mereka antusias menerima materi yang diberikan sehingga hal tersebut meningkatkan pengetahuan keluarga tentang DM meskipun tidak optimal.Hal ini disebabkan karena waktu yang cukup singkat dalam penelitian ini.

Hasil analisis menunjukkan skor kemampuan psikomotor keluarga sebelum pemberian psikoedukasi pada kelompok intervensi adalah 11,20 dan setelah mendapatkan terapi menjadi 15,75 dengan nilai $p$-value 0,0001 . Artinya terdapat perbedaan yang bermakna kemampuan keluarga aspek psikomotor pada kelompok intervensi antara sebelum dengan sesudah diberikan terapi psikoedukasi keluarga.

Dixon et al (2000, dalam Kembaren, 2011) mengatakan bahwa program psikoedukasi keluarga menawarkan kombinasi antara informasi tentang DM, praktek dan dukungan emosional, pengembangan keterampilan keluarga dalam problem solving dan manajemen krisis. Program tersebut bisa dilakukan untuk keluarga secara individu atau berkelompok dan memungkinkan untuk dilakukan di rumah keluarga, di klinik atau di lokasi lain. Pelaksanaan psikoedukasi keluarga sangat bervariasi dalam menentukan durasi dan lama waktu untuk setiap sesi dan bisa melibatkan pasien atau tidak dalam intervensi tersebut.

Perubahannya yang terjadi pada kemampuan psikomotor tidak seperti pada kemampuan kognitif, karena untuk merubah perilaku atau kemampuan psikomotor memerlukan waktu yang lebih lama dibandingkan dengan perubahan pada kognitif.Ditambah dengan perawatan pada DM bersifat jangka panjang (Videbeck, 2008). Hal ini menunjukkan bahwa keterampilan tertentu dapat dilatih melalui proses belajar sehingga mengalami peningkatan. Peran keluarga didalam perubahan perilaku ini sangat menentukan karena menurut Stuart \& Sundeen (2005), keluarga dapat memberikan perasaan mampu atau tidak mampu, diterima atau ditolak.

Penelitian lain yang dilakukan di Turki, umumnya masyarakat di Turki sulit untuk berkomunikasi hanya untuk menunjukkan penghargaan kepada orang lain. Selama ini mereka apabila ingin berbuat baik kepada orang lain dilakukan dengan pekerjaan dengan tidak mengatakan melalui komunikasi. Misalnya seorang ibu yang merasa bahagia dengan perlakuan suami, maka si ibu tersebut akan melakukan pekerjaan yang disenangi suami seperti membuat masakan yang disenangi suami. Namun setelah mendapatkan psikoedukasi keluarga maka mereka mulai belajar bagaimana berkomunikasi yang baik, memberi penghargaan dan pujian, hal tersebut sangat diperlukan khususnya oleh klien dengan DM.

Goldenberg dan Goldenberg (2004) menyatakan bahwa psikoedukasi keluarga adalah terapi yang digunakan untuk memberikan informasi terhadap keluarga yang mengalami distress, memberikan pendidikan kepada mereka untuk meningkatkan keterampilan agar dapat memahami dan mempunyai koping akibat penyakit DM yang mengakibatkan masalah pada hubungan keluarganya. Keluarga mendapatkan keterampilan bagaimana cara merawat klien DM di rumah serta mempunyai keterampilan untuk mengurangi beban dan stress yang dialami keluarga misalnya dengan teknik distraksi, relaksasi,tarik napas dalam serta teknik hipnotis lima jari.

Peningkatan kemampuan psikomotor pada kelompok intervensi dimungkinkan karena terapi psikoedukasi keluarga berkaitan dengan adanya komponen keterampilan latihan yang terdiri dari komunikasi, latihan menyelesaikan konflik, latihan asertif, latihan mengatasi perilaku dan mengatasi stress.Peningkatan kemampuan psikomotor ini kemungkinan berkaitan dengan teori belajar yang menjelaskan bahwa seseorang belajar bukan saja belajar dari pengalaman langsung tetapi dari peniruan dan peneladanan dengan memberikan pengetahuan dan latihan terstuktur serta konsisten sesuai dengan modul psikoedukasi keluarga yang telah disusun. Keluarga dilatih untuk merawat klien dengan dilibatkan secara langsung tentang cara merawat DM, 
manajemen stres dan beban serta memonitor kemampuan dan kegiatan klien sehari-hari.

Kemampuan psikomotor dalam merawat klien ditujukan pada kemampuan keluarga untuk senantiasa memberi pujian dan penghargaan pada klien, berupaya memberi dukungan pengobatan dengan membawa klien berobat ke pelayanan kesehatan.Pada penelitian ini waktu yang tersedia terbatas sehingga kemampuan keluarga belum terinternalisasi. Psikoedukasi keluarga melatih kemampuan psikomotor pada sesi 2 yaitu cara merawat klien DM, sesi 3 yaitu melatih manajemen stress. Sehingga pada pelaksaan untuk sesi tersebut harus lebih intens dan lama waktunya sampai benarbenar keluarga mampu melakukannya.

Penelitian ini juga membandingkan antara kelompok yang mendapatkan terapi psikoedukasi keluarga dengan kelompok yang tidak mendapatkan terapi psikoedukasi keluarga. Hasil yang didapat dalam penelitian ini yaitu pada kemampuan kognitif kelompok intervensi dengan nilai 7,90 sedangkan pada kelompok kontrol nilainya adalah 6,20. Pada kemampuan psikomotor pada kelompok intervensi didapatkan nilai 15,75 sedangkan pada kelompok kontrol dengan nilai 9,55. Hasil dari kedua kelompok tersebut dengan nilai $p$ value 0,0001 kurang dari nilai alpha 0,05 , artinya ada perbedaan yang bermakna antara kelompok yang mendapat terapi psikoedukasi keluarga dengan kelompok yang tidak mendapat terapi psikoedukasi keluarga. Hal ini menunjukkan terapi psikoedukasi keluarga sangat efektif dalam meningkatkan kemampuan keluarga baik kemampuan kognitif maupun psikomotor.

Psikoedukasi keluarga merupakan salah satu bentuk terapi perawatan kesehatan jiwa keluarga dengan cara pemberian informasi dan edukasi melalui komunikasi yang terapeutik (Stuart \& Laraia, 2005). Komunikasi terapeutik sangat diperlukan dalam menghadapi klien dengan DM pda lansia.

Manfaat program psikoedukasi bagi keluarga mendapatkan informasi dan pengetahuan tentang manajemen stress dan beban, peningkatan koping dan adaptasi serta diajarkan latihan dan keterampilan khusus untuk merawat klien dengan lansia DM. Hal ini sependapat dengan Keliat (2006) yang menyatakan bahwa angka kekambuhan pada pasien tanpa terapi keluarga sebesar $25-50 \%$, sedangkan angka kambuh pada pasien yang diberikan terapi keluarga sebesar $5-10 \%$.

Terapi psikoedukasi keluarga dapat meningkatkan kemampuan keluarga karena dalam terapi mengandung unsur meningkatkan pengetahuan keluarga tentang penyakit, mengajarkan teknik yang dapat membantu keluarga untuk mengetahui gejalagejala penyimpangan perilaku serta peningkatan dukungan bagi anggota keluarga itu sendiri. Tujuan program pendidikan ini adalah meningkatkan pencapaian pengetahuan keluarga tentang penyakit, mengajarkan keluarga bagaimana teknik pengajaran untuk keluarga dalam upaya membantu mereka melindungi keluarganya dengan mengetahui gejala-gejala perilaku danmendukung kekuatan keluarga (Stuart \& Laraia, 2005).

Analisa peneliti terkait dengan adanya perbedaan antara kelompok yang mendapatkan terapi dengan kelompok yang tidak mendapatkan terapi sudah sangat jelas. Kelompok intervensi selama beberapa pertemuan mendapatkan pengetahuan dan keterampilan cara merawat DM, sementara kelompok kontrol tidak mendapatkan pengetahuan baru. Kelompok kontrol selama penelitian hanya menerapkan yang selama ini mereka ketahui sementara pada kelompok intervensi mulai menerapkan pengetahuan tentang cara merawat klien DM di rumah. Namun peningkatan yang terjadi baik kemampuan kognitif maupun kemampuan psikomotor belum $100 \%$. Hal ini disebabkan waktu yang cukup singkat dalam proses pelaksanaan psikoedukasi keluarga, sehingga keluarga belum memahami sepenuhnya apa yang diberikan peneliti. Selain itu, dipengaruhi juga oleh kondisi kliennya, sehingga memerlukan usaha yang lebih kuat dari keluarga untuk terus memotivasi klien supaya dapat beraktivitas. 


\section{KESIMPULAN}

Psikoedukasi keluarga menunjukkan perbedaan yang bermakna pada kemampuan kognitif dan psikomotor keluarga dalam merawat klien dengan DM antara sebelum dan sesudah dilakukan terapi psikoedukasi keluarga.

\section{REFERENSI}

Arikunto, S., (2006). Prosedur Penelitian Suatu Pendekatan Praktek. Jakarta: Rineka Cipta.

Beandlands et.al., (2005). Caregiving by family and friends of adults receiving dialysis.Vol 32; 621-631. 2005. Proquest Nursing \& Allied Health Source diperoleh tanggal 2 Februari 2011

Depkominfo (2009). Jumlah lansia di Indonesia 16,5 juta orang. diperoleh tanggal 8 Februari 2011 dari http://www.depkominfo.go.id

Goldenberg I \& Goldenberg H. (2004). Family therapi an overview. Sixth edition. United states: Thomson
Psikoedukasi keluarga menunjukkan perbedaan secara bermakna antara kelompok yang mendapatkan terapi psikoedukasi keluarga dengan kelompok yang tidak mendapatkan terapi psikoedukasi keluarga di Kota Tasikmalaya

Keliat, BA. , (2006). Modul model praktek keperawatan profesional jiwa (MPKP Jiwa), Jakarta: WHO-FIK UI.

Notoatmodjo, (2007). Promosi kesehatan dan ilmu perilaku: PT rineka cipta

Stuart,G.W \& Laraia, M.T (2005). Principles and Practice of psychiatric nursing. (7th edition). St Louis: Mosby

Stuart G.W and Sundeen. (1995), Principles and Practice of Psyhiatric Nursing. St. Louis : Mosby Year B.

Weine S., et al. (2005). A family approach to severe mental illness in post-war kosovo.psychiatry 68 (1) 